\title{
Relation between Metacognitive Awareness and Participation to Class Discussion of University Students
}

\author{
Özkan Akman', Bülent Alagöz ${ }^{2, *}$ \\ ${ }^{1}$ Department of Social Studies and Turkish Education, Nizip Education Faculty, Gaziantep University, Turkey \\ ${ }^{2}$ Department of Basic Education, Nizip Education Faculty, Gaziantep University, Turkey
}

Copyright $\odot 2018$ by authors, all rights reserved. Authors agree that this article remains permanently open access under the terms of the Creative Commons Attribution License 4.0 International License

\begin{abstract}
Form of inquiry should be based on cognitive approach, student-centered, question and inquiry-based, free of memorization and focused on high-level cognitive skills (critical-creative thinking and problem-solving) rather than conventional teacher-centered teaching and learning based on memorization and behavioral approach. The life quality of human beings will be increased with thought sharing and discussion and this increase is achieved by means of an adequate development of mental faculties such as critical and creative thinking, raising metacognitive awareness and problem solving. The purpose of this study is to assess the perceptions of prospective teachers related to the correlation between metacognitive awareness and participation in discussion. There is no significant correlation found between grade level and departmental differences, gender and general academic scores, participation in discussion and metacognitive awareness scores of university students participated in this study. However, there was a positive correlation between number of books read and participation in discussion. Moreover, there was a moderately significant positive correlation between participation to discussions and metacognitive awareness.
\end{abstract}

Keywords Metacognitive Awareness, Controversial Issues, Class Discussion, Social Studies

\section{Introduction}

\section{Controversial Topics and Social Information}

I would challenge you to a battle of wits, but I see you are unarmed. (William Shakespeare). Form of inquiry should be based on cognitive approach, student-centered, question and inquiry-based, free of memorization and focused on high-level cognitive skills (critical, creative thinking and problem solving) rather than conventional teaching and learning based on memorization and behavioral approach, teacher-centered (72). This study is based on supporting the interaction of diverse perspectives on a closely focused topic or a task and allowing the group members to reach their own understandings in the light of the critically examined evidence. Debating is an important element in addressing controversial issues. Because, by debating, every child potentially has a chance to express himself/herself and the topics are dealt with more effectively; current views on a specific topic are recognized and the environment is utterly democratic because nobody can control the correct answer. In order to facilitate productive discussion, teachers should be interested in the topic and able to ask questions at important points that may help elaborate the discussion and listen to the children's reactions (59).

Students' discussion on controversial issues can be valuable in terms of constructing moral and civil opinions and replacing them and creating a chance for progress towards the objective to educate new conscious generations with people who participate in the democratic decision-making process (79). To say that people are involved in debating something, the following necessary and appropriate conditions must be existent:

- Being able to address a topic from multiple perspectives;

- At least being willing to assess and react to the different views expressed;

- Having an intention towards developing relevant knowledge, understanding and/or resolutions about the topic (13).

According Webster's New World Dictionary (62), there are two definitions of the discussion. First, definition refers to lasting discussions about a major problem with opposing opinions. The other one is 'discussion or controversy' (53). According to Vashist (85), the term controversial issue is used to determine any issue or problem with real or potential conflicts'. Most of the controversial issues can 
and should be discussed in class. According to the Education Policies Commission (USA), freedom of expression in controversial cases is more than a right and is a requirement of democratic institutions and democratic forms of life (12). Given these definitions, the scope of the controversial issues is considerably broad. Thus, it can be argued that controversial issues do comprise not only the issues directly affecting the students but also the ones that are causing problems in the adult world and that are currently unresolved. The content of the questions may vary from local issues to international issues. We can easily tolerate a child who is afraid of darkness. The main tragedy is that adults are afraid of light (Plato). The essence of a healthy democracy is an open dialogue with public opinion Therefore, discussing social, political and economic problems is an integral part of the education of young citizens.

Discussions include multiple perspectives. A mere conversation exchange with only one perspective or a prose passage cannot be considered as a discussion (44). However, articulation of various perspectives is not adequate for a discussion. Debaters should be sensitive to opinions other than their own. In relation to participating in a discussion, Bridges (13) argued that there should be a requirement of presenting different viewpoints, appreciation and abundance of presented ideas at least, if not a completely open mind to understand. According to him, it is not enough to present the views of people as if they are rehearsing frequently and passively, as in discussions between the politicians they oppose. Discussion requires that people are really willing to listen to and learn from each other. They change or renew their opinions in the light of expressed ideas. Debaters should be concerned about developing their knowledge, insight and judgment. This is the main difference in ordinary conversations with a discussion. Discussions are serious in this sense, whereas conversers and speakers who talk about ordinary topics can conventionally handle their subjects in a light or really fun way. Reaching the essence of a subject is the desire to obtain something correct and to separate the discussion from plain conversations or from unnecessary speech of uninformed people. Bridges (13) derived a set of essential moral hierarchies or principles from these necessary and adequate conversation conditions of interview that must be shared by the participants of verbal group discussions with at least one measurement separately from literary or individual discussion. These measures were making it necessary to be reasonable, peaceful, orderly, accurate, free, equal and respectful to the individual and implied that the quality of the classroom would be partially dependent on the degree to which the students would gain the necessary virtues and that learning to participate in discussion could help them develop these virtues (13).

Why is discussion a preferred method for teaching controversial topics? There are two fundamental causes.
Firstly, discussion is a convenient topic especially for evaluating different standing points in discussions and secondly, empathizing with those who defend them is a suitable subject. It is quite easy to theoretically convey what is happening in the classroom regarding a controversial issue in a tutorial or in explanatory ways to students. But the passionate and sincere attitudes of those who advocate opposing views with these tools are reasonable in the context of different old assumptions. And it is difficult to give information about ways to reconcile life experiences with people's identities through objections. The discussion, only introduces a different perception of appreciation, at least by means of representing opposing ideas within the group. Here, students are not abstractly interested in the stances in the theoretical array, but the sincere words of their friends and classmates (44). We educators, who are giving lectures that reveal correlation between pressure, abuse and authoritarian behavior in society, often face students who actively resist the discussion. These students resist the opinions of teachers, information in the textbooks and other course materials. In terms of morality, they legitimize the power of the existing system as they render the alternatives illegal. Students, who resist the discussions as they evaluate social life critically, do so because they tend to be reductionists in moral analysis and misunderstand the experimental and theoretical knowledge presented as moral arguments in lectures (47). The history of those who advocate teaching controversial topics is rooted in the past and includes the vast majority of impressive figures specialized in social studies $(64,30$ and 32). Each will make its own difficult choice in a way that will legitimize the teaching of controversial subjects in the class (53).

The teaching of controversial subjects is seen as preparing students for an effective citizenship in a broader sense. Learning about the content and thinking skills necessary for students to make decisions about public policy, to work successfully with their friends to reach consensus and to learn to negotiate and manage differences has outlined the general discipline of social studies. Thus, it is clear that while the world nation states continue to be closer to and more dependent on each other, educators, especially social studies educators, should play a greater role in the preparation of today's children for living in tomorrow's global village (53). Talking about controversial topics in social studies education is a matter of discussion among progressive educators, as it is in Africa, where children grow up by being told that they need to adapt to social life without questioning and knowing how they are going to deal with controversial issues (see. 17, 73 and 67).

A discussion of a controversial issue is defined as usage of a reflective dialogue about a topic in which there are disagreements among students or between teachers and students. The discussion is usually triggered by a question posed by the student or the teacher, or by a statement made. The subsequent dialogue allows the presentation of 
supporting evidence, interpretations and different perspectives. For this reason, the discussion, in its nature is an interactive effort and creates a reflective dialogue that listens to and responds the ideas expressed by the individual's peers. An idea or perspective can be seen as a problem if most of the people do not accept explanations, ideas, proposals, or claims put forward in the context of the idea or perspective. Controversial explanations based on alternative value systems and issues that deeply divide a community which produces solutions is a controversial topic. Given this definition, the scope of controversial topics is quite broad. The content of the questions may vary from local issues to international issues. The censorship of books in a school library, the immigration policy of the United States and the environmental situation of the world can be controversial issues with rich content. Each one encourages the expression of a wide range of views, although it reflects the problem area in the dimension of a different public policy making (81).

Debating of controversial issues is an important element of teaching social studies. There are various reasons to support the use of controversial topics in social studies classes. Three of the most common are as follows: (1) to prepare students for their roles as citizens in a pluralist democracy, (2) to improve their critical thinking skills and (3) to develop interpersonal skills. In order to teach controversial topics in social studies classes, each of the following points should be addressed carefully (46):

- Choosing topics: Teachers should consider the interests, experience and expertise of the students when choosing the discussion topics to make sure that topics are relevant to students' lives; they should consider the maturity level of their students and understand the importance of the subject in terms of society.

- Preparing students for discussion: Considering the inadequacy of the current courses, teachers should be enthusiastic about sparing time to train students for the controversial discussion techniques. Teachers and students should identify inter-class interaction rules together and both must understand that creating rhythms and being fluent in discussions will require practicality and patience.

- Providing sufficient information source: Ensuring that students are well-prepared to handle content in a discussion format requires teachers to be able to inform students about the sources of information so that students have the opportunity to acquire basic knowledge before debating. Background information can be provided by reading, lectures, movies, guest speakers and sightseeing.

- Creating an open discussion environment: Creating an intellectually safe environment for student involvement is one of the most important elements of successful discussions. Teachers should model appropriate debating behavior by carefully listening to and respecting the contributions of the students. Teachers should respect different views and encourage expressing such views to create a space that does not pose a threat to the display of ideas. Students should understand that they do not have to interrupt each other's comments and that they will be able to participate in the discussion without experiencing any negativity.

- Maintaining focus and orientation: One of the most common problems faced by discussion leaders is the tendency to encourage discussion while handling the subject. Teachers can create the necessary platform for constructive discussions by using the blackboard or overhead projector and developing a discussion agenda and summarizing and organizing student contributions. The discussion agenda may include identification of the problem, summarizing and analyzing the evidence, suggestions for possible solutions, hypothesizing the results of the solutions and correlating them with the personal experiences of the students.

- Equilibrating the intellectual balance: One of the primary roles of the teacher in managing class discussions is to ensure that students have a comprehensive overview of each issue that is addressed. Teachers should require students to have detailed knowledge of the topics discussed and prepare their students for the best-case scenario and for a fair listening of the opposing views. The fact that an important point of view is not indicated can be revealed through careful teacher questioning; or by asking students to act on someone who will present perspective.

- Encouraging equal participation: In order to reach a level of equal participation, it is often necessary to actively attract silent students into the discussion and to limit the contributions of more open-minded students. Establishing an accession system usually helps to solve this problem. Student involvement can be guided, for example, through the use of medallions or signs. Each student is given the number of "tokens" they spend while contributing in the discussion. After all the students have exhausted their tokens, the tokens are re-split. Such a method to guide the discussion will help to equalize the individual participation of the students.

- Expression of teacher's personal ideas: Teachers who teach controversial topics in the class want to state that these are opinions only and should be willing to provide evidence on which their decisions are based. In addition, teachers should be prepared to reflect their stance and for their students' challenging them, since all opinions expressed should be questioned and examined while discussing controversial issues. It is the most 
natural right of all citizens in democratic societies to exhibit a stance in one subject; teachers should be careful, but in doing so, they should not adversely affect students' ability to freely study the issues discussed or being discussed (46).

We must prepare students, as a young citizen, to deal with a wide range of social problems. Newmann (63) asserted that the main task of democratic citizens is to discuss the nature of public property with other citizens and how it is going to be done. Therefore, social studies classrooms should serve as a laboratory where students can experiment on democratic processes. Teaching controversial topics is also recommended as a means of improving students' critical thinking. By discussing controversial issues, students develop cognitive skills such as hypothesis development, evidence collection and evaluation. It also benefits from exchanging information with peers. When students participate in discussions, they develop important attitudes and communication skills such as listening carefully, responding empathetically, persuasive speaking and easily collaborating with others in the group. Well-managed discussions also allow different views on each subject to be tolerated.

Learning how to enter into a dialogue with people whose values are different from yours and to respect people is at the center of the democratic process; it is also essential for the protection and strengthening of democracy and for the development of a human rights culture. However, young people in Europe usually do not have the opportunity to discuss controversial issues at school, because it seems very difficult to teach topics such as extremism, gender violence, child abuse or sexual orientation. It does not seem possible for the youth to express their concerns. Young people who cannot make their voices heard, do not know how others feel, or rely on their friends and social media for this, live in confusion about their societies and the main issues affecting today's European society. If there is no help from the school, there are no reliable tools to make the students to deal with these issues and no one to guide them. Public concerns emerged after the events of high profile violence and social disorder in different European countries, have combined with the ideas of the consideration of controversial issues at schools, new democracy and human rights and making education a priority issue. Firstly, events such as the 2011 London uprising, the 2011 Norwegian hate crimes and the Charlie Hebdo attack in Paris in 2015 have led to a comprehensive review of the role schools play in the moral and civic development of young people in these countries and throughout Europe. Secondly, the European democracy and human rights education policy has been oriented towards inclusion of active and participatory learning and "real life" topics rather than course book practices and theoretical knowledge and there is an increasing consensus on this subject. There is a growing consensus that democratic citizenship, respect for human rights and intercultural understanding can be learned better by "doing" rather than "knowing". As a result, democratic citizenship and human rights education curricula throughout Europe have become open to new, unpredictable and controversial types of teaching content (19).

Over the past 25 years, academics in the field of social sciences have been examining the effects of discussing controversial issues through experimental research. The investigation line came up with a groundbreaking review of Patrick's political socialization research. According to Patrick (68), their education programs could have a greater impact on the development of democratic attitudes "if conducted in a more favorable environment for investigation and open-mindedness". A number of researchers later investigated the role of the discussion in preparing students for citizenship. Research on the effects of discussion has shown that students participating in class discussions exhibit a more favorable political attitude in political activities and the participation rate in such activities is high. Adults who recall school discussion and participants in those discussions were rated higher than their counterparts in political efficacy criteria (68). Long and Long (54) concluded that the discussion of controversial issues in schools is a correlation between ongoing current events in the media and discussion of political issues with friends and family.

An important element in discussing productive controversial issues highlighted by researchers is the importance of creating a class climate that is conducive to free expression of ideas. Taken as a whole, students who discuss controversial topics in social studies classes are making positive progress in terms of political interest, efficacy and confidence (43). In addition, it was understood that the discussions raised citizens' tolerance (42) and increased interest in social issues (22). Specific climate variables contributing to the positive effects of the discussion on controversial issues provided a wide array of the ideas, the freedom of the students to express opinions (28) and the perception of the students that teachers were willing to discuss ideas (54). Each of the class climate elements has shown that the discussion of controversial issues is associated with positive citizen attitudes. Discussing controversial issues, not only promotes the development of positive political attitudes, but also produces more favorable attitudes towards social studies courses in general. Students have expressed that they both want to investigate controversial social issues and have more positive feelings about social studies courses that comprise discussion formats (71). With more discussion of controversial topics, social studies courses are not linked to the real world and the number of students who think they are boring is likely to be low, as is frequently reported in research on students' perceptions of social issues.

Making useful discussions in controversial issues is an art that requires skill and practice. Teachers should pay 
attention to their role that will take place in discussion in order to prepare for discussions and to ensure that the interactions are fruitful. Those who teach the correlation between exploitation, oppression and sovereignty in society often face students who are actively resisting these discussions. While challenging our information needs, such students are resistant to challenging the claims of our textbooks and other course materials, morally legitimizing the existing system of power and making the alternatives spiritually illegitimate. University students represent a diverse population of dynamic individuals. Students resist for controversial issues for a variety of reasons, such as personality conflicts with teachers, daily stress, effects on emotional rights and genuine intellectual disagreement. When they start the university, they realize they will have to take various courses to get a degree. They rarely challenge the validity of information presented to them, even if they can complain about courses such as economics and philosophy (47).

Controversial issues that can be defined as issues that generate strong emotions and divide opinions in communities and societies range from local to global, for example, from the construction of mosques to the reduction of greenhouse gas emissions. Some are remaining in the agenda for a long time, such as inter-sectarian divisions among communities. Others are far more recent: such as the radicalization of young people around Islam in European countries are. They also vary according to time and space. The atrocities in the school may be highly controversial in one country, but may also be an accepted part of life in another. Similarly, bilingual education, bottled water or the Islamic headscarf are also controversial topics. Almost any topic can always create controversy and new discussions can arise day by day. Controversial issues represent great values and interest conflicts when combined with controversial claims about underlying facts. They tend to be complicated by non-compliant answers. They create strong emotions and tend to create or strengthen divisions that create suspicion and distrust among people (19).

More than one curriculum model, aimed at preparing teachers for providing education to students with different qualifications, characterized the contemporary curriculum landscape (29). Teachers of anti-repressive education (50), critical multicultural education (56), feminist pedagogy (21) and culturally related pedagogy (52), suggest frameworks, methods and strategies that guide teaching and learning-oriented preparation. It is known that when it is time to plan and teach lessons, teachers have the freedom to decide what to and how to teach $(11,83)$. Social sciences teachers have the responsibility to present their students various perspectives in different ways that will provide them with the opportunity to practice their democratic citizenship skills and to make presentations on different topics (60). This means that students discuss and are prepared and determined not only in terms of the history of civilization, but also in terms of the development of today and tomorrow of humankind. This often means that controversial issues - or issues that create controversy belong to the lessons of social studies (19).

\section{Metacognitive Awareness}

Metacognitive awareness consists of beliefs and knowledge about factors such as task, individual and strategy that interact during any cognitive activity. Metacognition is defined as the student's own knowledge of the learning task or learning process (18). Wenden (88) classified metacognition knowledge into three different but related pieces of information: personal information (general information that can facilitate or impede learning such as age, language abilities, motivation, etc.); task information (information about the purpose of a mission; the aforesaid information such as the nature of a specific task and knowledge and skills required to complete a task also includes the information that a duty necessitates) and strategic information (strategy used for managing, navigating and organizing learning). Social sciences teachers and prospective teachers with no metacognitive awareness may not succeed in using controversial subjects as an effective teaching method in social studies classes, similar to the case of the "One cannot give what he does not own" (7) called as the Peter Effect. It will not be easy for a prospective teacher who is unaware of his or her accumulation, competence and abilities and oneself to succeed in solving everyday problems and providing good training to his/her students when they start teaching profession. As Yunus Emre has said: "Knowledge is to understand: to understand who you are. If you do not know who you are What's the use of learning?. Education will not go beyond a useless effort if it does not function as a guide in the self-identification process of the individual. It is widely acknowledged that growing mobile libraries, make students to find cities on empty maps, to give the best marks to the one who gives the best memorized information does not contribute to growing individuals who think critically and creatively and solve problems are self-confident and self-realized.

Metacognition; is an important concept that has maintained its popularity in the field of cognitive psychology and education since the 1970s. Metacognition is defined in many different ways depending on context. John Flavell was the first to use this term in the field of education. Flavell (35) explained the metaphor in the following way; Metacognition refers to the individual's knowledge of cognitive processes and output or his/her knowledge about anything related to them. According to Dunslosky \& Thiede (27), metacognition is individual's usage of high-level mental processes such as planning to learn, using appropriate strategies and skills to solve a problem, making predictions about his/her performance and adjusting learning dimensions. Briefly, metacognitive 
awareness involves recognition of what the individual does or does not know, controlling his or her mental processes, taking the learning responsibility, being aware of his/her own learning strategies, evaluating his own learning, planning, monitoring and managing his knowledge. While many students use metacognitive strategies while reading books, it cannot be argued that all students know how and why to use them. Strategy utilization is a developmental issue which argues that there may be a difference based on the academic year (5). Awareness-raising and monitoring, are very important processes of discussing controversial issues and qualified reading $(4,69,76)$. Metacognitive awareness involves the strategy to be utilized and knowing which strategy fits the task (82).

The view that metacognition is important for learning has been widely accepted. According to most teachers and researchers, students' thinking about their own learning strategies and mental processes makes them more successful. It is also stated that the metacognition plays an important role in improving self-regulation skills, problem solving and critical thinking. The formation of metacognition has been a subject that has been studied extensively by educational psychologists since the 1970 s $(9,35,37,70,90)$. Definitions vary according to context (41). The well-known and widely spoken aspect of metacognition is that it develops over time (87). Strategies can be taught and adopted, but they do not always get narrated to the contexts (37). Researches have also shown that a large proportion of children and adults tend to fail to monitor their thoughts, especially when performing routine tasks (39). Many studies have been conducted on the concept of metacognition for the past 25 years (45). It can be argued that there are not enough studies on the subject in our country and that there is not yet a consensus on the naming of the concept. The concept of cognitive awareness has been included in the literature in our country with various expressions. Erden \& Akman (31) defined the concept of "metacognition" as "cognition knowledge" with its original name; Açıkgöz (1) and Demirel (23) defined it as "metacognitive"; Aral (6) as "metacognitive information"; Senemoğlu (78) as "executive cognition"; Küçük-Özcan (51) and Demir-Gülşen (24) as "metacognition"; Bedir (10) as "the way of using information" and Doğanay (26) as "cognitive awareness" (40).

The difference between metacognition and cognition is another important aspect of the field. According to Brown (14), the difference between metacognition and cognition that the person is aware of the cognition in metacognition and it can be used suitably for circumstances. Garner (38) explained the difference between cognition and metacognition as follows: Cognition is the information required to perform a task or solve a problem and the metacognition is the information needed to understand how a task is performed or a problem is solved (77). Flavell (35) and Baker (8) defined metacognition as the cognitive processes that one has in a broader sense. Despite many different definitions in the literature, according to many researchers, the metacognition consists of two main components $(33,36,57,58,61,74)$. These are cognitive information and cognitive regulation skills. While cognitive knowledge is related to the information obtained through cognitive processes and the ability to control cognitive processes, cognitive strategies are about whether cognitive activities are controlled and cognitive goals are achieved (45). While cognitive information is relevant for how one person knows and understands learning paths and memory, cognitive adjustment skills are related to how a person organizes and adjusts his/her learning and memory. Cognitive information is divided into three groups. These are the Declarative Knowledge, Procedural Knowledge and Conditional Knowledge. Explanatory knowledge is our knowledge of how we learn and what affects how we learn. Methodological knowledge is our knowledge of the best learning and memory techniques for us. Conditional Knowledge, on the other hand, is the knowledge of where we can use different cognitive strategies. For an overall evaluation, cognition knowledge is our knowledge of how we learn, our knowledge of which strategies and paths are effective when we learn and knowledge of in which situations cognitive activities are most effective for us (75). Cognitive regulation skills are, unlike cognitive knowledge, the actual activities that will strengthen one's learning and memory. Cognitive regulation skills are divided into five groups. These are; Planning Strategies, Monitoring Strategies, Evaluation Strategies, Debugging Strategies and Information Management Strategies (74).

If students have developed their cognitive regulation skills and their cognitive knowledge, that means they are using their metacognition and they are academically superior. Thus, it is very important to investigate the correlation between academic achievement of students and their metacognitive knowledge and skills (89). In some studies, it was found that there is a significant correlation between achievement level and cognitive regulation skills $(24,16)$. Hence Sperling, Howard, Staley, \& DuBois, (80) found a positive relationship between components of metacognition, cognitive knowledge and cognitive regulation skills and academic achievement. Kruger \& Dunning (49) noted the importance of metacognition in learning because it is a powerful predictor of academic success. Students with strong metacognitive awareness perform better and think more strategically than students with weak metacognitive awareness $(20,37)$. Yet, Everson \& Tobias (33) suggested that metacognition makes students more strategic in learning. Metacognitive awareness provides students with the opportunity to plan, to monitor and to evaluate their own learning so that students who take their own responsibilities in all parts of the learning process apply their knowledge to encountered problems more easily and become more successful (74). Successful students are those who are aware of when they 
act and do not act strategically. Effectiveness is related to whether it is done consciously (65).

Human intelligence is primarily developed through speaking and listening. Our life quality depends on the quality of our thinking and our ability to share and discuss with others. Speech, literacy and associating with others are specific to us, unique to our abilities. This is the basis of verbal and emotional intelligence. Teaching dialogue skills to children is a purpose in itself and a fundamental thought and communicative competence that forms the basis for other skills such as creativity, reasoning and metacognition. What children need to be able to succeed by solving their problems is to learn to listen to each other as adults, to be responsive to others' ideas and willing to change their ideas by thinking about others (34).

The life quality of human beings will increase with thought sharing and discussion and this increase is achieved by means of an adequate development of mental faculties such as critical and creative thinking, raising metacognitive awareness and problem solving. Despite the obvious connection between metacognitive awareness and discussion, there was no study investigating the correlation between metacognitive awareness and controversial topics and social studies education, especially in the domestic literature. Therefore, the aim of this research is to assess the correlation between the metacognitive awareness of prospective teachers and their views on participating in discussion.

\section{Research Questions}

1. Is there a correlation between demographic variables (grade levels and departmental differences, gender and general academic scores and number of books read) and participation in discussion?

2. Is there a correlation between metacognitive awareness and participation in discussion?

3. How extensively does metacognitive awareness predict participation in discussion?

\section{Method}

\section{Sample}

The sample of this study was composed of 229 students studying at the education faculty of a university located in the South-East region of Turkey. Using stratified sampling method, it is ensured that at least 30 students from each grade participate in the study. 75 first grade students, 40 second grade students, 71 third grade students and 43 fourth grade students participated in the study. The age of the students ranges from 18-29. However, the majority of the students are between the ages of 18-23. 107 teacher candidates from social studies teaching department, 55 from primary school teaching department and 67 from Turkish language teaching department participated in the study. 164 of the teacher candidates participated in the study are women and other 65 are men.

\section{Data Collection Tools}

The aim of this research is to reveal the correlation between the views of education faculty students on participating in discussion and their metacognitive awareness. Thus, Metacognitive Awareness Inventory developed by Schraw \& Dennison (74) and validated by Akın, Abacı, \& Cetin (2) in Turkish and Classroom Discussion Scale developed by Kelly (48) and validated as Discussion Participation Scale (3) in Turkish were used. Discussion Participation Scale, which is the first dimension of the discussion participation scale consisting of three sections, was used in this study. In this study, only the first dimension of the Discussion Participation scale consisting of three sections was used. The reason behind this is that the first dimension is related to the thoughts of students on discussion participation and the other two dimensions reveal their experiences. Only the first dimension was used as a data collection tool as the aim in this study was to determine students' thoughts.

\section{Metacognitive Awareness Inventory}

Metacognitive awareness inventory consists of two main parts. The first part, which is cognitive knowledge, is to know what you know about yourself, what strategies you use and what strategies are better in which situations. Explanatory, conditional and procedural knowledge are considered to be the three main concepts that constitute conceptual knowledge. The first cognitive knowledge part contains Explanatory Knowledge, Procedural Knowledge and Conditional Knowledge, while the second part, in which the cognition is organized, contains Planning, Monitoring, Evaluation, Debugging and Knowledge Management sub-factors. The second part is to know the strategies and ways and monitoring, correcting and evaluation activities that the student uses in his/her learning. The first factor, "explanatory knowledge" contains beliefs about the individuals' structure of learning tasks, cognitive goals and personal abilities and consists of 7 items. "I am aware of my mental strengths and weaknesses" can be shown as an example of the items in this factor. The second factor, "procedural knowledge", consists of 4 items. The items collected under this factor assess the level of knowledge on how to use the strategies to solve a problem and the level of using and organizing knowledge and skills of the individual. "I am aware of which strategies I use when working" can be shown as an example of the items. The third factor is the "conditional knowledge". The items of this factor measure when and why the individual uses descriptive and procedural knowledge and the 
sub-dimension consist of 6 items. "I know which strategies would be more useful" can be shown as an example item of situational knowledge. Explanatory knowledge, procedural knowledge and situational knowledge are under main dimensions of cognition knowledge. The fourth sub-dimension is "planning". The items collected at this factor include the choosing appropriate learning strategies and implementing cognitive resources for effective performance and consist of 7 items. "I think of different ways to solve a problem and choose the best one among them" can be shown as an example of these items. The "monitoring", which is determined as the fifth factor, consists of 8 items. The items under this factor reflect the analysis of the individual's performance, estimation of future performance, evaluation of the efficiency of learning strategies and the identification of performance errors. "I regularly check whether I can achieve my goals" can be shown as an example of these items. The sixth factor is "evaluation" and consists of 6 items. The items in this factor measure the individual's evaluation of learning outcomes and productivity. "I make a summary of what I learned after completing my studies" can be given as an example of the items under the evaluation dimension. The seventh factor in inventory is "debugging". The items under this factor include correcting individual's errors in the performance and understanding; and this sub-item consists of 5 items and "I change the strategies that I use when I cannot understand the knowledge" can be shown as an example of the items under this sub-dimension. The eighth and last factor is "knowledge management". The items under this factor include skills such as organizing, detailing, summarizing, etc., to process knowledge more efficiently and consist of 9 items. "I divide my work into small steps while studying" can be given as an example of these items. The factors of planning, monitoring, evaluation, debugging and knowledge management are under the main dimension of cognition organization.

\section{Discussion Participation Scale}

The discussion participation scale originally consists of three main parts. The first factor consists of 13 items related to participating in discussion and measures the thoughts of the individual participating in discussion. It consists of 13 items, 7 of which are reverse. Statements such as "I have difficulty in expressing my ideas" and "I enjoy class discussions" can be given as examples of these items. The first of the two other factors is the Factors Affecting Participation and the second is the Discussion as a Value. In this study, the reason behind using discussion participation sub-scale is to determine only the thoughts of participants related to the discussion. The other two sub-dimensions are rather related to the experience of the participants.

\section{Findings}

Metacognitive awareness inventory sub-dimensions and general reliability scores used in this study are given in the table below.

Table 1. Metacognitive awareness inventory reliability coefficients

\begin{tabular}{|c|c|}
\hline Dimensions & Cronbach's Alpha Reliability Coefficient \\
\hline Explanatory Knowledge & .73 \\
\hline Procedural Knowledge & .60 \\
\hline Declarative Information & .68 \\
\hline Planning & .77 \\
\hline Monitoring & .76 \\
\hline Evaluation & .68 \\
\hline Debugging & .66 \\
\hline Knowledge Management & .78 \\
\hline General & .95 \\
\hline
\end{tabular}

When the coefficients of general reliability and coefficients of sub-dimensions are examined, it can be concluded that this inventory is reliable. According to DeVellis (25), it is ideal that the Cronbach Alpha coefficients are greater than 0.7. However, when the number of items in each sub-dimension is less than 10 , the Cronbach Alpha coefficient is commonly found around 0.5 (66). The sub-dimensions with coefficient below 0.7 are those below 10. The reliability coefficient of the participation in discussion scale was calculated as 0.79 in this study.

\section{The Correlation between Demographic Variables and Participation in Discussion}

Whether or not there is a correlation between demographic variables and participation in discussion was examined by interaction analysis. There was no statistically significant correlation between grade level and departmental differences, gender and general academic scores of students participating in the study and their participation in discussion. Likewise, there was no significant correlation between demographic variables and metacognitive awareness. However, it is found that there is a significant correlation between book reading and the participating in discussion score. The correlation between book reading and participating in discussion is given in the table below.

According to Table 2, it is discovered that there are significant differences between those who read 1-5 books, those who read 6-10 books and those who read books over 21 books. Accordingly, as the number of book readings increases, the participation in discussion scores also increase. 
Table 2. One-way variance analysis results of the correlation between book reading and participation in discussion

\begin{tabular}{|c|c|c|c|c|c|c|}
\hline $\begin{array}{c}\text { Number of } \\
\text { Books }\end{array}$ & $\mathrm{N}$ & Mean & $\begin{array}{c}\text { Std. } \\
\text { Deviation }\end{array}$ & $\mathrm{f}$ & $\mathrm{P}$ & $\begin{array}{c}\text { The groups } \\
\text { with } \\
\text { difference }\end{array}$ \\
\hline $1-5(1)$ & 65 & 2.7156 & .39529 & & & \\
\cline { 1 - 4 } $6-10(2)$ & 58 & 2.8848 & .45381 & \multirow{2}{*}{5.64} & 0.001 & $1-2,1-4$ \\
\hline $11-20(3)$ & 40 & 2.8875 & .49801 & & \\
\hline $\begin{array}{c}\text { 21 and over } \\
(4)\end{array}$ & 69 & 3.0423 & .49481 & & & \\
\hline Total & 232 & 2.8847 & .47278 & & & \\
\hline
\end{tabular}

\section{Is There a Correlation between the Participation Scores of the Discussion and Metacognitive Awareness?}

A correlation analysis was performed to determine whether there was a statistically significant correlation between metacognitive awareness and participation in discussion.
Table 3. Participation in discussion and metacognitive awareness correlation analysis

\begin{tabular}{|c|c|c|c|}
\hline \multicolumn{2}{|c|}{} & $\begin{array}{c}\text { Participation in } \\
\text { discussion }\end{array}$ & $\begin{array}{c}\text { Metacognitive } \\
\text { Awareness }\end{array}$ \\
\hline \multirow{3}{*}{$\begin{array}{c}\text { Participation in } \\
\text { discussion }\end{array}$} & $\begin{array}{c}\text { Pearson } \\
\text { Correlation }\end{array}$ & 1 & $.305^{* *}$ \\
\cline { 2 - 4 } & Sig. (2-tailed) & & .000 \\
\cline { 2 - 4 } & $\mathrm{N}$ & 232 & 232 \\
\hline \multirow{3}{*}{$\begin{array}{c}\text { Metacognitive } \\
\text { Awareness }\end{array}$} & $\begin{array}{c}\text { Pearson } \\
\text { Correlation }\end{array}$ & $.305^{* *}$ & 1 \\
\cline { 2 - 4 } & Sig. (2-tailed) & .000 & \\
\cline { 2 - 4 } & $\mathrm{N}$ & 232 & 232 \\
\hline
\end{tabular}

**. Correlation is significant at the 0.01 level (2-tailed).

Here is a moderately significant correlation (.30-.49 moderate significance) between metacognitive awareness and participation in discussion according to the table ( $\mathrm{r}$ $=.30, \mathrm{n}=232, \mathrm{p}<.005)$. It means that as metacognitive awareness increases, participation in discussion increases. The correlation between the sub-dimensions of the metacognitive awareness inventory and participation in discussion was also examined. This correlation is given in the table below.

Table 4. The relationship between sub-dimension of metacognitive awareness inventory and participation in discussion

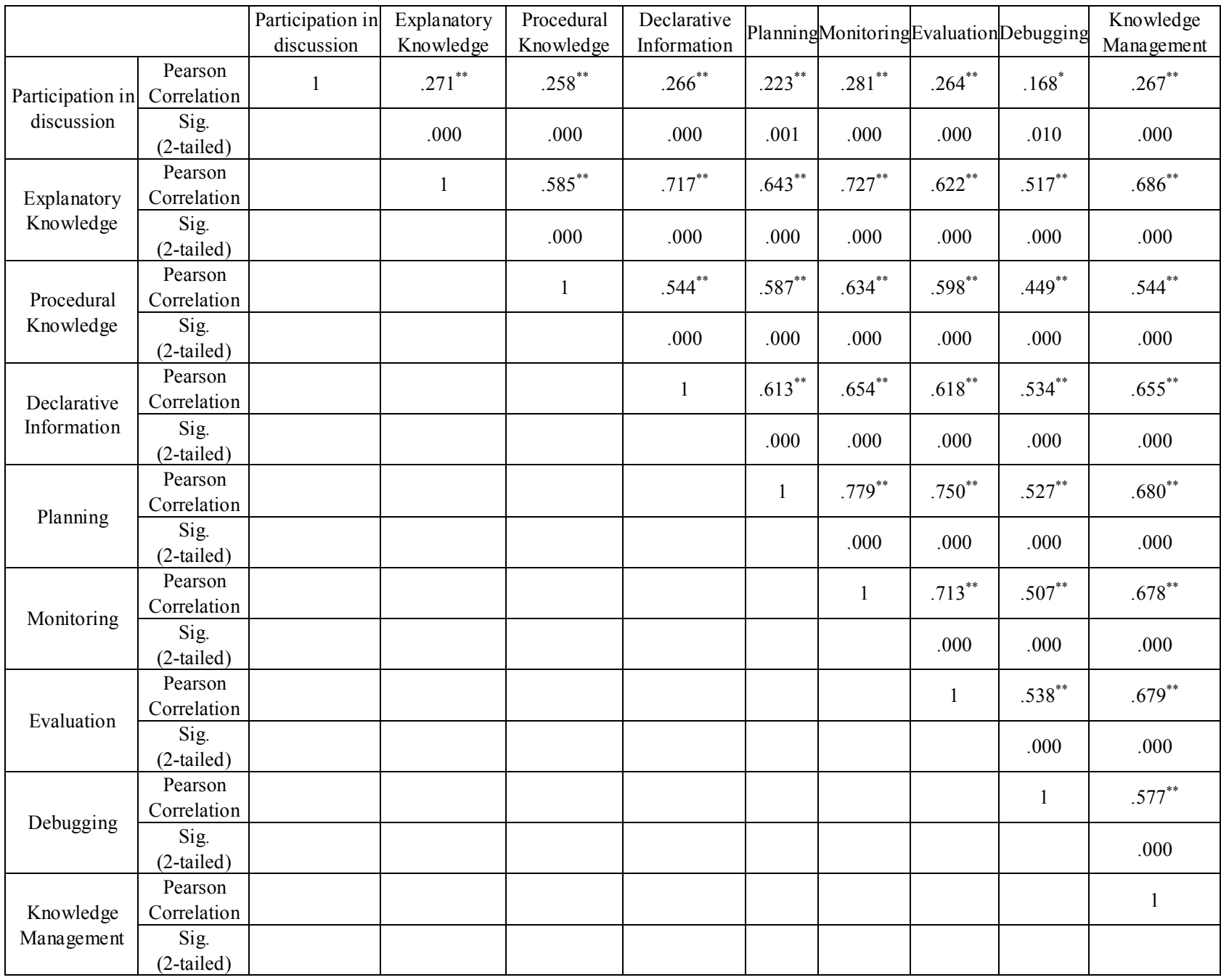

**. Correlation is significant at the 0.01 level (2-tailed).

*. Correlation is significant at the 0.05 level (2-tailed). 
Significant relationships were found between the participation in discussion and the sub-dimension of the metacognitive awareness inventory. However, as seen in the table, these effects are all weak effects. The correlation coefficient of all of them is under 30 . They have a moderate effect jointly.

\section{How Extensively Does Metacognitive Awareness Predict Participation in Discussion?}

A simple linear regression analysis was performed to determine whether the metacognitive awareness and its sub-dimensions predict participants' participation in discussion or not.

Before the simple linear regression analysis is performed, it is necessary that there are no extreme values of the data that will enter the regression. For this purpose, Mahalanobis distances of data should be analyzed. Mahalanobis distance critical value with 7 sub-dimensions and one general total in 8 variant regression analyzes is 26.13 (55). Four kinds of data analysis that larger than 26.13 were excluded from the study. The VIF values are checked to determine if there is a multi-colinearity problem in the data set. All of the VIF values are below 10, indicating that there is no problem in the data set related to co-linearity (66).

Table 5. Simple linear regression analysis on participation in discussion

\begin{tabular}{|c|c|c|c|c|c|c|c|c|c|c|c|}
\hline \multicolumn{2}{|c|}{$\begin{array}{c}\text { Model 1 } \\
\text { Variables }\end{array}$} & \multicolumn{9}{|c|}{ The predicted variable: Participation in discussion } \\
\cline { 2 - 12 } & $\mathrm{B}$ & Std. Error & Beta & $\mathrm{t}$ & Sig. & $\begin{array}{c}\text { Zero-order } \\
\text { Correlations }\end{array}$ & $\begin{array}{c}\text { Partial } \\
\text { Correlations }\end{array}$ & $\begin{array}{c}\text { Part } \\
\text { Correlations }\end{array}$ & Tolerance \\
\hline \multirow{2}{*}{1} & Constant & 1.859 & .221 & & 8.409 & .000 & & & & & \\
\cline { 2 - 12 } & $\begin{array}{c}\text { Metacognitive } \\
\text { Awareness }\end{array}$ & .279 & .059 & .298 & 4.699 & .000 & .298 & .298 & .298 & 1.000 & 1.000 \\
\hline
\end{tabular}

$\mathrm{R}=0.298$

$R^{2}=0,089$

As seen in table 5, participant's metacognitive awareness levels have a significant $(\mathrm{F}(1,226)=22.08, \mathrm{p}=.000)$ effect on participation in discussion. According to this model, the metacognitive awareness levels of the students explain $8.9 \%$ of the variance of SBS achievements $\left(\mathrm{R}=.298, \mathrm{R}^{2}=.089\right)$.

Multiple regression analysis (Enter method) was performed to determine which sub-dimensions of metacognitive awareness are correlated with participation in discussion. There are information management, debugging, monitoring, evaluation and planning in cognitive editing skills while explanatory, procedural and conditional knowledge are included in the cognitive knowledge sub-dimension. Multiple regression analysis results are given in the following table.

Table 6. The sub-dimensions regression analysis

\begin{tabular}{|c|c|c|c|c|c|c|c|c|c|c|c|}
\hline & \multirow{2}{*}{ Model } & \multicolumn{2}{|c|}{ Unstandardized Coefficients } & \multirow{2}{*}{$\begin{array}{c}\begin{array}{c}\text { Standardized } \\
\text { Coefficients }\end{array} \\
\text { Beta } \\
\end{array}$} & \multirow[t]{2}{*}{$\mathrm{t}$} & \multirow{2}{*}{ Sig. } & \multicolumn{3}{|c|}{ Correlations } & \multicolumn{2}{|c|}{ Colinearity Statistics } \\
\hline & & B & Std. Error & & & & Zero-order & Partial & Part & Tolerance & VIF \\
\hline \multirow{4}{*}{1} & (Constant) & 1.832 & .219 & & 8.385 & .000 & & & & & \\
\hline & $\begin{array}{l}\text { Explanatory } \\
\text { Knowledge }\end{array}$ & .077 & .081 & .093 & .952 & .342 & .267 & .063 & .060 & .423 & 2.366 \\
\hline & $\begin{array}{c}\text { Procedural } \\
\text { Information }\end{array}$ & .128 & .063 & .165 & 2.022 & $.044^{*}$ & .279 & .134 & .128 & .605 & 1.654 \\
\hline & $\begin{array}{l}\text { Declarative } \\
\text { Information }\end{array}$ & .079 & .072 & .103 & 1.099 & .273 & .262 & .073 & .070 & .457 & 2.189 \\
\hline \multirow{6}{*}{2} & (Constant) & 1.952 & .218 & & 8.966 & .000 & & & & & \\
\hline & Planning & -.056 & .088 & -.077 & -.641 & .522 & .230 & -.043 & -.041 & .285 & 3.506 \\
\hline & Monitoring & .193 & .092 & .241 & 2.094 & $.037 *$ & .292 & .139 & .134 & .309 & 3.232 \\
\hline & Evaluation & .070 & .084 & .091 & .828 & .408 & .254 & .056 & .053 & .341 & 2.930 \\
\hline & Debugging & -.026 & .059 & -.037 & -.450 & .653 & .155 & -.030 & -.029 & .608 & 1.646 \\
\hline & $\begin{array}{l}\text { Knowledge } \\
\text { Management }\end{array}$ & .078 & .080 & .096 & .967 & .335 & .249 & .065 & .062 & .414 & 2.415 \\
\hline
\end{tabular}

As seen in the table, there is a significant correlation between procedural knowledge and monitoring sub-dimensions and participation in discussion. According to this, it can be seen that the process information and monitoring sub-dimensions can predict participation in discussion. A stepwise regression analysis was performed to determine which of these two sub-dimensions could better predict. Stepwise regression results are given in the table below. 
Table 7. The Stepwise linear regression analysis of the participation in discussion

\begin{tabular}{|c|c|c|c|c|c|c|c|c|c|c|c|}
\hline \multirow{2}{*}{\multicolumn{2}{|c|}{$\begin{array}{c}\text { Model } 1 \\
\text { Variables }\end{array}$}} & \multicolumn{10}{|c|}{ The predicted variable: Participation in discussion } \\
\hline & & B & Std. Error & Beta & $\mathrm{t}$ & Sig. & Zero-order Correlations & Partial Correlations & Part Correlations & Tolerance & VIF \\
\hline \multirow{2}{*}{1} & Constant & 2.050 & 0.185 & & 11.094 & .000 & & & & & \\
\hline & Monitoring & .234 & .051 & .292 & 4.592 & .000 & .292 & .292 & .292 & 1.000 & 1.000 \\
\hline
\end{tabular}

$\mathrm{R}=0.292$

$R^{2}=0,085$

According to Table 7, there is a significant correlation between the Participation in Discussion and the sub-dimension of Metacognitive Awareness (F $(1,228)=$ $21.089 ; \mathrm{p}=.000)$. According to this model, the Monitoring sub-dimension alone accounts for $8.5 \%$ of the participation in discussion $\left(\mathrm{R}=.292 ; \mathrm{R}^{2}=.085\right)$. The procedural knowledge sub-dimension is derived from the regression equation in this model.

\section{Conclusions and Discussion}

There is no significant correlation found between grade level and departmental differences, gender and general academic scores of university students who participated in this study and their participation in discussion and metacognitive awareness scores. However, there is a positive correlation between number of books read and participation in discussion. In other words, as the number of books read increases, the demand for participation in discussions increases as well. The limit values in the book reading are 5-10 and above 20 . In other words, it can be said that readers who read more than 20 books are inclined to participate in discussions and the ones who read 10 are more inclined than those who read 5 books. The book is a magic thing that takes you away from the chair you are sitting in to distant lands (Katrina Mayer). The vocabulary of students who read books increases and this allows them to think and speak with more words. The thoughts that pass through their minds are expressed with more accurate words. Developing these faculties is a necessity for teacher candidates who are able to speak fluently and express themselves more clearly, because they will raise generations that we entrusted our future. Being teachers who speak their mother tongue fluently and who are aware of developments and constantly renew themselves in this context, who read much, follow books written in all fields of social sciences closely and express their thoughts by using Turkish language effectively in various platforms is a task and obligation for prospective teachers and this is the most important assurance that the country is brought to light and democracy smoothly operates with all institutions and rules.

There is a moderately significant positive relationship between participation in discussion and metacognitive awareness. Accordingly, as the participants' metacognitive awareness increases, their participation in discussion also increases. There is a weak correlation between sub-dimension of metacognitive awareness and participation in discussion. When sub-dimensions are merged, the effect of this correlation increases. As metacognitive awareness can be defined as knowledge of the individual's life, his/her past, his/her talents, his/her qualifications, why he/she should learn, what and how he/she learns and what kind of a learning process is more appropriate for him/her; then the ability of discussion is to discover one's potential, to develop the ability to express oneself, to speak the mother tongue more effectively, to know which information is necessary for the topic being discussed for himself/herself and to efficiently utilize that information in the process of discussion and to have an apparatus that will enable to develop critical and creative thinking skills as one of the most important outcomes of the learning process; the presence of a statistically positive correlation between participation in discussion and metacognitive awareness is highly significant.

To determine whether metacognitive awareness predicts participation in discussion, a simple linear regression was performed first. Accordingly, metacognitive awareness accounts for $8.9 \%$ of the variance in participation in discussion. Multiple regression analysis was conducted to determine which sub-dimension of metacognitive awareness explains participation in discussion. According to the results of multiple regression analysis, it is seen that the procedural knowledge and monitoring sub-dimensions can predict participation in discussion. A stepwise regression analysis was performed to determine which of these two sub-dimensions was more influential and it was observed that only the monitoring sub-dimension alone estimated the $8.5 \%$ of participation in discussion rate. The monitoring sub-dimension indicates individual's analyzing his/her performance, his/her estimation of future performance, assessment the effectiveness of learning strategies and identification performance errors. Then, in order to increase participation in discussion, it becomes important that the individual actually over-watches and evaluates oneself internally. In his study, Wade (86) has presented the individual factors in participating in class discussions as attitudes of classmates and the teacher behavior. He stated that individual factors were not clear, but that students might be afraid to participate in discussions because of their friends' attitude. In this study, it was found that monitoring the sub-dimension of metacognitive awareness can predict $8.5 \%$ of participation in discussion. The estimation of the performance of the person in the monitoring sub-dimension has become 
important in identifying performance errors on participation in discussion.

\section{REFERENCES}

[1] Açıkgöz, K., Ü. (2016). Etkili Öğrenme ve Öğretme (9. Bask1). Biliş Yayıncılık, Ankara.

[2] Akin, A., Abaci, R., \& Çetin, B. (2007). The validity and reliability of the Turkish version of the metacognitive awareness inventory. Educational Sciences: Theory \& Practice, 7(2), 671-678.

[3] Alagoz, B. (2014). Classroom Discussion Scale of Wade: Adaptation to Turkish, Validity and Reliability Study. International Journal of Academic Research in Business and Social Sciences, 4 (12), 42-57, DOI: 10.6007/IJARBSS/v4-i1 1/1327

[4] Alexander, p. a., \& Jetton, T.L. (2000). Learning from text: A multidimensional and developmental perspective. In $\mathrm{m}$. Kamil, P. Mosenthal, P. Pearson, \& R. Barr (Eds.), Handbook of reading research (pp. 285-310). Mahwah, NJ: Lawrence Erlbaum Associates Inc.

[5] Alexander, P. A., Graham, S., \& Harris, K. R. (1998). A perspective on strategy research: Progress and prospects. Educational Psychology Review, 10 (2), 129-154. http://dx.doi.org/10.1023/A:1022185502996

[6] Aral, A. O. (1999). Guessing and metacognitive knowledge (Master Thesis) Retrieved from Council of Higher Education Thesis Center (Thesis No. 92031).

[7] Arrastia, M. C., Zayed, A. M., \& Elnagar, H. Z. (2016). Metacognitive Awareness of Reading Strategies among English as a Foreign Language (EFL) Preservice Teachers: An Exploration of Gender and Developmental Differences. International Research in Higher Education, 1(2), 46-55. https://doi.org/10.5430/irhe.v1n2p46

[8] Baker, L. (2002). "Metacognition in comprehension instruction". In C. Block \& M. Pressley (Eds.), Comprehension instruction: Research-based best practices (pp. 77-95). New York: Guilford.

[9] Barzilai, S., \& Zohar, A. (2014). Reconsidering personal epistemology as metacognition: A multifaceted approach to the analysis of epistemic thinking. Educational Psychologist, 49 (1), 13-35.

http://dx.doi.org/10.1080/00461520.2013.863265

[10] Bedir, H. (1998). The effects of using cognitive learning strategies on reading comprehension ability of Turkish students (Doctoral Dissertation), Retrieved from Council of Higher Education Thesis Center (Thesis No. 64914).

[11] Bickmore, K., \& Parker, C. (2015). Constructive conflict talk in classrooms: Divergent approaches to addressing divergent perspectives. Theory and Research in Social Education, 42, 291-335.

http://dx.doi.org/10.1080/00933104.2014.901199.

[12] Boahene, L. A. (2007) Creating strategies to deal with problems of teaching controversial issues in social studies education in African schools, Intercultural Education, 18(3),
231-242, DOI: 10.1080/14675980701463588.

[13] Bridges, D. (1979). Education, Democracy and Discussion. University Press of America.

[14] Brown, A. L. (1980). "Metacognitive development and reading". In R. J. Spiro, B.C. Bruce, \& W.F. Brewer (Eds.), Theoretical issues in reading comprehension (pp. 458-482). Mahwah, NJ: Erlbaum.

[15] Brown, A. L. (1987). "Metacognition, executive control, self-regulation and other more mysterious mechanisms". In F. Weinert \& R. Kluwe (Eds.), Handbook of Child Psychology: Vol. 3. Cognitive Development (pp. 263-340). New York: Wiley.

[16] Case, L. P., Harris, K. R., \& Graham, S. (1992). Improving the mathematical problem-solving skills of students with learning disabilities Self-regulated strategy development. The Journal of Special Education, 26(1), 1-19. DOI: $10.1177 / 002246699202600101$

[17] Chapin, J. R. (2012). Elementary social studies: A practical guide. Pearson.

[18] Chen, C. C., \& Tseng, D. S. (2017). "I give up and stop listening": Fostering metacognitive listening strategy awareness in the English class guestrooms in Taiwan. Advances in Social Sciences Research Journal, 4(11), 14-22, DOI:10.14738/assrj.411.3268

[19] Council of Europe. (2017). Managing controversy Developing a strategy for handling controversy and teaching controversial issues in schools. Council of Europe Publishing.

[20] Coutinho, S. (2008). Self-efficacy, metacognition and performance. North American Journal of Psychology, 10(1), $165-172$

[21] Crabtree, R. D., Sapp, D. A., \& Licona, A. C. (2009). Introduction: The passion and the praxis of feminist pedagogy. In R. D. Crabtree, D. A. Sapp, \& A. C. Licona (Eds.), Feminist pedagogy: Looking back to move forward (pp. 1-20). Baltimore, MD: Johns Hopkins University Press.

[22] Curtis, C. K., \& Shaver, J. P. (1980). Slow Learners and the Study of Contemporary Problems. MT Social Education, 44(4), 302-309.

[23] Demirel, Ö. (2012), Eğitim sözlüğü, Dictionary of Education. PegemA Yayınları (5. Baskı), Ankara

[24] Demir-Gülşen, M. (2000), “A model to investigate probability and mathematics achievement in terms of cognitive, metacognitive and affective variables" (Master Thesis). Retrieved from Council of Higher Education Thesis Center (Thesis No. 95378).

[25] Desoete, A., \& Roeyers, H. (2002). Off-line metacognition a domain-specific retardation in young children with learning disabilities. Learning Disability Quarterly, 25(2), 123-139. DOI: $10.2307 / 1511279$

[26] DeVellis, R. F., (2003). Scale Development, Theory and Applications. $2^{\text {nd }}$ Edition, Sage Publications, Thousand Oaks, CA).

[27] Doğanay, A. (1997), "Ders dinleme surasında bilişsel farkındalıkla ilgili stratejilerin kullanımı". Çukurova Üniversitesi Eğitim Fakültesi Dergisi, 28(5), 34- 42. 
[28] Dunslosky, J., \& Thiede, K.W. (1998). "What makes people study more? An evaluation of factors affects self-paced study". Acta Psychologica, 98(1), 37-56. https://doi.org/10.1016/S0001-6918(97)00051-6

[29] Ehman, L. (1977). Social Studies Instructional Factors Causing Change in High School Students' Sociopolitical Attitudes over a Two-Year Period. Paper presented at the annual meeting of the American Educational Research Association, New York, April 1977. ED 142480.

[30] Engebretson, K. E. (On publishing phase). One novice teacher and her decisions to address or avoid controversial issues. The Journal of Social Studies. https://doi.org/10.1016/j.jssr.2017.03.001

[31] Engle, S. H., \& Ochoa, A. (1988). Educating citizens for democracy: Decision-making in social studies.

[32] Erden, M. \& Akman, Y. (1996). Eğitim Psikolojisi: Gelişim, Öğrenme ve Öğretme. Ankara: Arkadaş Yay.

[33] Evans, R. W., \& Saxe, D. W. (1996). Handbook on Teaching Social Issues. NCSS Bulletin 93. National Council for the Social Studies, 3501 Newark Street, NW, Washington, DC 20016-3167.

[34] Everson, H. T., \& Tobias, S. (1998). “The ability to estimate knowledge and performance in college: A metacognitive analysis". Instructional Science, 26(1), 65-79. DOI: 10.1023/A:1003040130125

[35] Fisher, R. (2007). Dialogic teaching: developing thinking and metacognition through philosophical discussion, Early Child Development and Care, 177(6-7), 615-631, DOI: 10.1080/03004430701378985.

[36] Flavell, J. H. (1979). "Metacognition and cognitive monitoring: A new area of cognitive developmental inquiry". American Psychologist, 34 (10), 906-911. http://dx.doi.org/10.1037/0003-066X.34.10.906

[37] Flavell, J. H. (1987). "Speculations about the nature and development of metacognition". In Metacognition, motivation, and understanding, F. E. Weinert, \& R. H. Kluwe (Eds.), (pp. 21-29). Hillsdale, NJ: Lawrence Erlbaum.

[38] Garner, R., \& Alexander, P.A. (1989). "Metacognition: Answered and unanswered questions", Educational Psychologist, 24 (2), 143-158.

http://dx.doi.org/10.1207/s15326985ep24022

[39] Garner, R. (1987). Metacognition and reading comprehension. Norwood, NJ: Ablex.

[40] Garner, R. (1990). When children and adults do not use learning strategies: Toward a theory of settings. Review of Educational Research, 60 (4), 517-529. http://dx.doi.org/10.3102/00346543060004517

[41] Gelen, İ. (2004). Bilişsel Farkındalık Stratejilerinin Türkçe Dersine İlişkin Tutum, Okuduğunu Anlama ve Kalıcılı̆̆a Etkisi. XIII. Ulusal Eğitim Bilimleri Kurultayı'nda sunulan bildiri, 6-9 Temmuz 2004, İnönü Üniversitesi Eğitim Fakültesi, Malatya.

[42] Georghiades, P. (2004). From the general to the situated: Three decades of metacognition. International Journal of Science Education, 26(3), 365-383. http://dx.doi.org/10.1080/0950069032000119401
[43] Goldenson, D. R. (1978). An Alternative View about the Role of the Secondary School in Political Socialization: A Field Experimental Study of the Development of Civil Liberties Attitudes. Theory and Research in Social Education 6(1), 44-72.

[44] Hahn, C. L., Angell, A., \& Tocci, C. (1988). Civic Attitudes in Five Nations. A paper presented at the International meeting of the Social Studies. Vancouver, British Columbia canada.

[45] Hand, M., \& Levinson, R. (2012). Discussing Controversial Issues in the Classroom. Educational Philosophy and Theory, 44 (6), 614-629. DOI:10.1111/j.1469-5812.2010.00 732.x.

[46] Hangrove, R. A. (2007). Creating creativity in the design studio: Assessing the impact of metacognitive skill development on creative abilities (Doctoral dissertation). Retrieved from https://repository.lib.ncsu.edu/bitstream/handle/1840.16/30 48/etd.pdf?sequence $=1 \&$ isAllowed $=\mathrm{y}$

[47] Harwood, A. M., \& Hahn, C. L. (1990). Controversial Issues in the Classroom. ERIC Digest.

[48] Hedley, M., \& Markowitz, L. (2001). Avoiding Moral Dichotomies: Teaching Controversial Topics to Resistant Students. Teaching Sociology, 29(2), 195-208.

[49] Kelly, T. (1986). Discussing controversial issues: four perspectives on the teacher's role. Theory and Research in Social Education, $14 \quad$ (2), $113 \quad$ - 138. http://dx.doi.org/10.1080/00933104.1986.10505516

[50] Kruger, J., \& Dunning, D. (1999). Unskilled and unaware of it: how difficulties in recognizing one's own incompetence lead to inflated self-assessments. Journal of personality and social psychology, 77 (6), 1121-1134.

http://dx.doi.org/10.1037/0022-3514.77.6.1121

[51] Kumashiro, K. (2002). Troubling education: Queer activism and anti-oppressive pedagogy. New York: Routledge Falmer.

[52] Küçük-Özcan, Z. Ç. (2000). Teaching metacognitive strategies to 6th grade students (Master Thesis). Retreived from Council of Higher Education Thesis Center (Thesis No. 95435).

[53] Ladson-Billings, G. (2014). Culturally relevant pedagogy 2.0: Aka the remix. Harvard Educational Review, 84(1), 74 84. https://doi.org/10.17763/haer.84.1.p2rj131485484751

[54] Lewis, A. B. (2007). Creating strategies to deal with problems of teaching controversial issues in social studies education in African schools. Intercultural Education, 18(3), 231-242, DOI: 10.1080/14675980701463588

[55] Long, S., \& Long, R. (1975). Controversy in the classroom: Student viewpoint and educational outcome. Teaching Political Science, 2(3), 275-299. http://dx.doi.org/10.1080/00922013.1975.10740053

[56] Martin, W. E., \& Bridgmon, K. D. (2012). Quantitative and statistical research methods: From hypothesis to results (Vol. 42). John Wiley \& Sons.

[57] May, S., \& Sleeter, C. (2010). Critical multiculturalism: Theory and praxis. New York: Routledge. 
[58] Mazzoni, G. F., \& Nelson, T. O. (2014). Metacognition and Cognitive Neuropsychology. Monitoring and Control Processes. Psychology Press.

[59] Metcalfe, J., \& Shimamura, A. P. (1994). Metacognition: Knowing about knowing. Cambridge. MA, Massachusetts Institute of Technology Press.

[60] Myhill, D. (2007). Reading the World: Using children's literature to explore controversial issues. In H. Claire \& C. Holden (Eds). The Challenge of Teaching Controversial Issues, Stoke-on-Trent, Trentham.

[61] National Council for Social Studies (1994). Expectations for Excellence: Curriculum Standards for Social Studies. Washington, D.C.

[62] Nelson, T. O., \& Narens, L. (1990). "Metacognition: A Theoretical Framework and New Findings". In G. Bower (Edt.). The Psychology of Learning and Motivation (pp. 125-141). San Diego, CA: Academic Press.

[63] Neufeldt, V., \& Sparks, A. N. (2002). Webster's new world dictionary. Simon and Schuster.

[64] Newmann, F. M. (1989). Reflective Civic Participation. Social Education, 53(6), 357-359

[65] Oliver, D. W., \& Shaver, J. P. (1966). Teaching public issues in the high school. Boston: Houghton Mifflin.

[66] Özsoy, G. (2008). Üstbiliş. Türk Eğitim Bilimleri Dergisi, 6(4), 713-740.

[67] Pallant, J. (2016). SPSS Survival Manual. McGraw Hill Open University Press, England.

[68] Parker, W. C. (2011). Social Studies in Elementary Education, (14th Edition). Pearson.

[69] Patrick, J. J. (1967). Political Socialization of American Youth: Implications for Secondary School Social Studies. Washington, D.C.: National Council for the Social Studies, ED 010835 .

[70] Pressley, M. (2000). What should comprehension instruction be the instruction of? In M. Kamil, P. Mosenthal, P. Pearson, \& R. Barr (Eds.), Handbook of Reading Research (pp. 285-310). Mahwah, NJ: Lawrence Erlbaum Associates Inc.

[71] Quintana, C., Zhang, M., \& Krajcik, J. (2005). A framework for supporting metacognitive aspects of online inquiry through software-based scaffolding. Educational Psychologist, 40(4), 235-244. http://dx.doi.org/10.1207/s15326985ep40045

[72] Remy, R. C. (1972). High School Seniors' Attitudes toward Their Civics and Government Instruction. Social Education, 36 (6), 590-597.

[73] Rudduck, J. (1986). A Strategy for Handling Controversial issues in the Secondary School. In J. J. Wellington (Edt.), Controversial Issues in the Curriculum, Oxford, Blackwell.

[74] Schell, E., \& Fisher, D. (2007). Teaching Social Studies: A literacy-based approach. Pearson Merrill Prentice Hall.

[75] Schraw, G., \& Dennison, R.S. (1994). "Assessing Metacognitive Awareness". Contemporary Educational
Psychology, 19(4), 460-475,

https://doi.org/10.1006/ceps.1994.1033

[76] Schraw, G., \& Moshman, D. (1995). "Metacognitive Theories". Educational Psychology Review, 7(4), 351-371. DOI: $10.1007 / \mathrm{BF} 02212307$

[77] Schraw, G. (1998). Promoting general metacognitive awareness. Instructional Science, 26(1), 113-125. http://dx.doi.org/10.1023/A:1003044231033

[78] Schraw, G. (2001). "Promoting General Metacognitive Awareness". In H. J. Hartman (Ed.), Metacognition in learning \& instruction, (pp. 3-16). Dordrecht, The Netherlands: Kluwer Academic Publishers.

[79] Senemoğlu, N. (2009), Gelişim, Öğrenme ve Öğretim. Ankara: Pegem Akademi Yayıncılık. (1. Bask1).

[80] Solomon, J. (1992). The Classroom Discussion of Science-Based Social Issues Presented on Television: Knowledge, attitudes and values. International Journal of Science Education, 14 (4), 431-444. http://dx.doi.org/10.1080/0950069920140406

[81] Sperling, R. A., Howard, B. C., Staley, R., \& DuBois, N. (2004). Metacognition and self-regulated learning constructs. Educational Research and Evaluation, 10(2), 117-139.

[82] Stradling, R. (1984). Controversial Issues in the Classroom. In S. Hill \& C. Reid (Eds). Teaching Controversial Issues, London: Edward Arnold.

[83] Tarricone, P. (2011). The taxonomy of metacognition. New York: Psychology Press.

[84] Thornton, S. J. (2004). Silence on gays and lesbians in social studies curriculum. In D. J. Flinders \& S. J.

[85] Thornton (Eds.). The Curriculum Studies Reader. Routledge.

[86] Vashist, S. R. (2002). Encyclopedia of Teaching of Social Studies. Anmol Publications.

[87] Wade, R. C. (1994). Teacher education students' views on class discussion: implications for fostering critical reflection. Teaching \&Teacher Education, 10(2), 231-243 https://doi.org/10.1016/0742-051X(94)90015-9

[88] Weil, L. G., Fleming, S. M., Dumontheil, I., Kilford, E. J., Weil, R. S., Rees, G., Dolan, R. J., \& Blakemore, S. J. (2013). The development of metacognitive ability in adolescence. Consciousness and Cognition, 22(1), 264-271. http://dx.doi.org/10.1016/j.concog.2013.01.004

[89] Wenden, A. L. (1998). Metacognitive knowledge and language learning 1. Applied Linguistics, 19(4), 515-537. https://doi.org/10.1093/applin/19.4.515

[90] Young, A., \& Fry, J. D. (2008). Metacognitive awareness and academic achievement in college students. Journal of the Scholarship of Teaching and Learning. 8 (2), 1-10.

[91] Zimmerman, B. J. (1995). Self-regulation involves more than metacognition: A social cognitive perspective. Educational Psychologist, 30(4), 217-221. http://dx.doi.org/10.1207/s15326985ep30048 